\title{
Conceptual Model for the Study of Strategic Cooperation in Small and Medium-Sized Companies: A Theoretical Essay
}

\author{
Francisco Alberto Severo de Almeida \\ Jorge Manoel Adão \\ Zenaide Dias Teixeira \\ Marcelo Duarte Porto \\ Universidade Estadual de Goiás \\ Brazil
}

\begin{abstract}
This theoretical essay presents the conceptual model called The Systemic Dimensions for the study of Business Cooperation in Small and Medium Enterprises, having as reference the strategic dimensions; organizational; of products and / or services and marketing. A theoretical mapping is done regarding the cooperation strategy; organizational architecture; strategy and systemic approach; organizational culture; innovation, competitiveness; essential skills; market positioning; market segmentation and marketing compound. Finally, it presents a series of questions aimed at understanding the process of business cooperation in Small and Medium Enterprises, as a contribution to future discussions.
\end{abstract}

Keywords: Business cooperation; Business strategy; Small and medium companies.

\section{Introduction}

The search for competitive advantage in companies has resulted in strategic actions focused on technological innovations and in changes in the modeling of new products or services. The dynamics of the competitive market environment favors the application of business strategies aimed at business consolidation as well as construction and the renewal of capacities that feed value formation for the Company.

On the other hand, environmental business changes resulting from the growth of globalized markets have established a series of barriers that oppress the growth and development of small and medium-sized businesses, whether for economic, market, government policy or even technology reasons. As a way of transposing these barriers, small and medium-sized companies from various market segments have as strategic growth the formation of strategic cooperation. Strategic alliances stand out as an important tool in business cooperation. According to Wright, Kroll and Parnell (2000) strategic alliances are partnerships that allow joint venture formation, franchise / licensing agreements, joint research and development, joint operations, joint agreements for long-term supply, joint marketing agreements and consortia.

The companies adopt the strategic cooperation with the most distinct goals: ever since the sharing of risks in investments; economies of scale, focusing on reducing costs to increase their competitive power; access to a market segment; geographic expansion of business, access to technology, leveraging core competencies and even overcoming competition barriers by increasing their competitive advantage. The strategic cooperation also promotes the leveraging of the management of the technological innovation of the companies, basing and strengthening their entrepreneurial skills. Porter (2002) emphasizes that the only way for small businesses to thrive in the long run is by understanding how they may be different from other companies.

In this scenario, it is important to highlight the importance of small and medium-sized enterprises to the economies of the countries in the last decades. In Brazil, according to national SEBRAE data $(2002,2014), 99.69 \%$ of the enterprises are classified as micro, small and medium-sized enterprises and employ $62.6 \%$ of the economically active population. In Portugal, SMEs account for $99.5 \%$ of the business sector and generate $74.7 \%$ of employment, according to IAPMEI - INE, for 1998. In Italy, companies with less than 100 employees account for $99 \%$ of the total and produces $70 \% \%$ of jobs (Silva, 2005). More than $99 \%$ of the 18 million companies in the European Union in various market sectors, other than agriculture, are SMEs. These companies employ $66 \%$ of the workforce and creates $55 \%$ of total turnover. In Chile, it is estimated that micro, small and medium-sized enterprises together hold a share of between 15\% and 20\% of GDP and about $80 \%$ of the total workforce in the country (DMPME, 2002). 
Considering the representativeness chart of Small and Medium Enterprises in the Brazilian business structure, it is clear that the adoption of cooperative strategies constitutes a valuable tool to promote a competitive leverage of these organizations. The partnership between companies, through cooperation agreements, opens path for the development and access to new technologies, new products, sharing of risks in investments, access to new markets, economy of scale and reduction of operational costs.

Therefore, the insertion of SMEs into the globalized market leads us to seek the understanding of the use of cooperation strategies under a systemic approach. The cooperation process, seen as an open, integrated and interdependent system of organizational structure, technology, corporative culture, operating in constant interaction with the market (environment), allows the understanding and evaluation of the desired results and those obtained by the company in cooperation agreements. In this context, this theoretical essay aims to present a conceptual model for the study of strategic cooperation in small and medium enterprises. The model described is called The Systemic Dimensions of Strategic Cooperation.

\section{Material and Methods}

Small and medium-sized enterprises are structured based on the principles and foundations of the classical administration theory that guides and disciplines the administrative action of these organizations, through a set of strict rules and standards that delimit the level and field of performance of each administrative area. SME management practices and models base their concepts on the classic management approach - Taylor, Fayol, of strictly Cartesian foundations to characterize a management system (Almeida, 2000). Morgan (2009) emphasizes that mechanistically structured organizations have a greater difficulty adapting to situations that changes because they are designed to achieve predetermined goals and are not planned for innovation. For (Peters and Waterman, 1982) although the conventional business reality seems to be nowadays a driving forcepropulsive to business, it is simply unable to explain the biggest part for much of what makes high-end firms work.

Therefore, small and medium enterprises that overcome the market adversities of the first years of life are submitted to a competition based on new concepts and values of the globalized market and, in a systemic way, identify the new business opportunities and then define their strategies for growth. According to Hart (1999), the systemic view of business processes allows the company to create scenarios about the future, without the restrictions of the current thinking about the current business. Farah (2001) reinforces the thoughtaffirming that the successful entrepreneur is the one who does not remain passive to the changes that occur in the organizational ecosystem, but to the one that seeks to anticipate them. For Mintzberg (1998), the fundamental dilemma in formulating a strategy is the need to reconcile the forces of stability and change and maintain the connection of the changing external environment.

Management practice, adopted by most small and medium-sized enterprises, is based on a typically reactive organizational culture, always prone to solving the organization's day-to-day and emerging problems. Administrative actions are established according to the mechanistic concepts and values that delimit the level and field of performance of each administrative area. This way, the company is understood by the sum of its parts and not by its whole: the totality. This shortsightedness of management gives rise to a dichotomous view of the manager in relation to the company and the market. Its organizational reality is limited to the internal environment of the company, relegating the external environment to the background. Hence their difficulties in adapting to changing environments and therefore taking a proactive management stance.

Thus, the understanding and analysis of a strategic cooperation process must be based on the premises of the organization as a system. System defined as the set of integrated and interdependent parts that constitute a dynamic process of interaction, creating a totality: the organization and the environment in a fast pace of change. The cooperative strategy requires of the managers of companies a holistic vision, focused in the business. The new market scenario has required competent managers to promote product and / or services innovation and create key competencies to achieve organizational goals and meet the market demand. Thus, the entrepreneurial vision of the small and medium enterprise manager must be systemic, directed also to the market and not just to the product and / or service.

So, under the premise of organization by system, the conceptual model named The Systemic Dimensions of Strategic Cooperation (Figure 1) to study SMEs is organized into four interdependent and interactive parts that complement each other in a continuous process of interrelationship described as: strategic management; organizational management; product and / or service management and marketing management and thus defined:

- Subsystem of strategic management is represented by the management of the company and aims to establish policies and guidelines regarding relevant decisions on the strategy of cooperation of the organization.

- Organizational subsystem is responsible for the process of organizational modeling to implement the policies and guidelines of the organization's strategic cooperation; 
- Subsystem of products and / or services is responsible for the development of products and / or services, originating from a cooperation agreement. Emphasis on the employment of a productive process based on new methods, processes and technologies; and

- Marketing subsystem that is responsible for developing the marketing policies and strategies of the organization, object of a cooperation agreement, forproduct design, development, deployment and product evaluationwith the consumer.

Figure 1 - Systemic dimensions of Business Cooperation

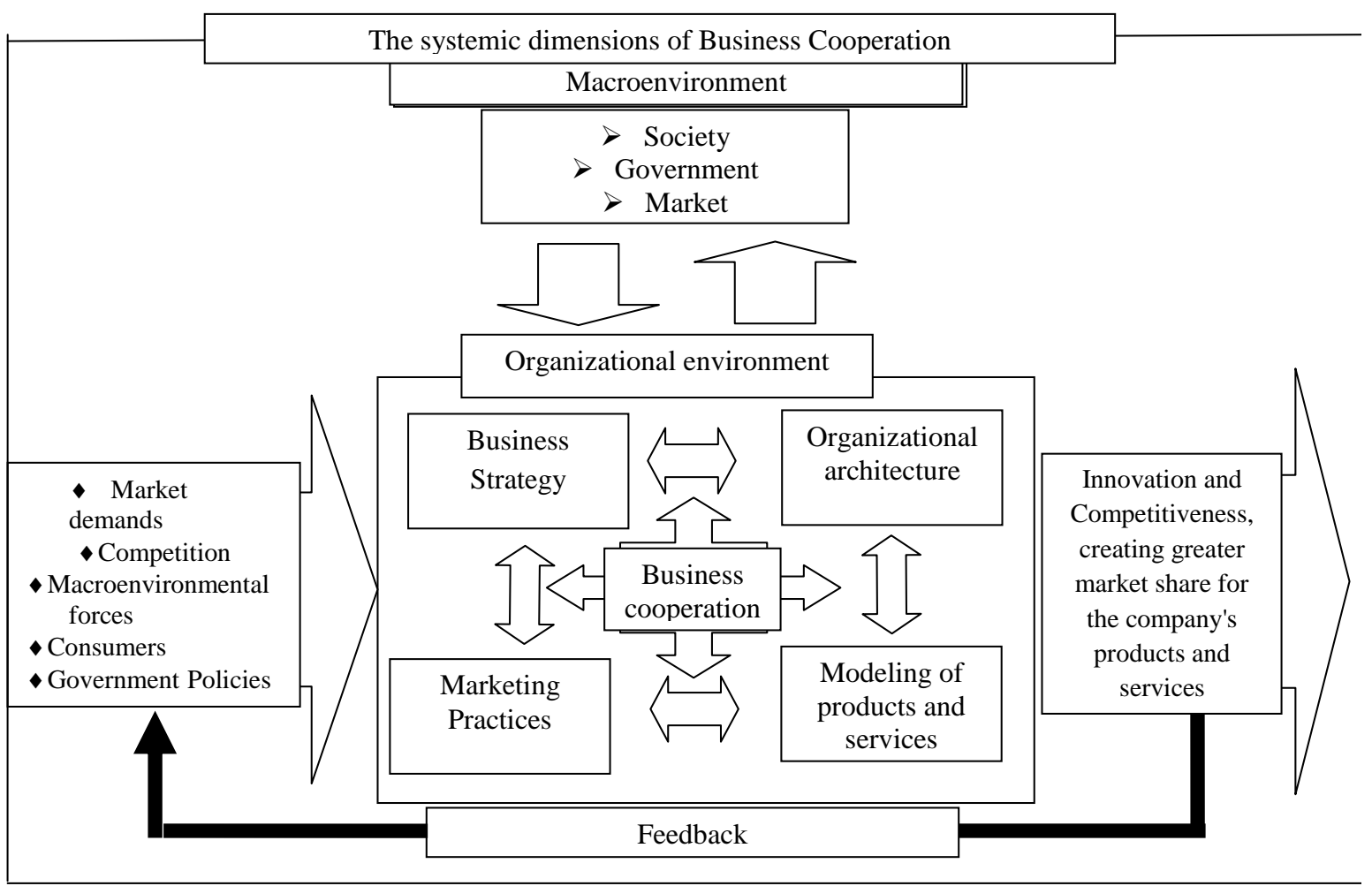

Source: Adapted from Almeida (2001)

Understanding management practices and organizational renewal, indispensable conditions for the survival of a company in contemporary society, of great, complex and rapid changes in all sectors, it is necessary to know its structure and functioning, not only in relation to its constituted parts, but rather in relation to the set of parts that merges them and the set of relations that are formed from their interactions. Business management, under a system approach, allows an understanding of organizational reality by its set and not by its parts. System theory is basically interested in the problems of relations, structure and interdependence and not by the constant attributes of the object. (KATZ and KAHN, 1987). Migliato and Escrivão (2004), in proposing an organizational design model for SMEs, affirm that the interrelationship and interdependence properties existing between the specifics of the small company are evident only with the use of a systemic model that considers the environment and organizational components.

The modern administrative management has its technical foundations structured from the set of organizational, technological, behavioral and environmental elements based on the concept of systemic administration. The systemic process translates into the constant exchange of information betweenparts, in an interdependent way, and with permanent interaction, building a dynamic whole. According to CAPRA (1998, 260) "Systemic properties are destroyed when a system is dissected, physically or technically, in isolated elements. Although we can discern individual parts in any system, the nature of the whole is always different from the mere sum of its parts. "

However, this dichotomous view of business management - scientific administration and systemic administration - is little noticed in SMEs, given the predominance of classic concepts in management. Nobrega (2000: 243) makes the following statement: In the business world, we are still very much attached to the linearity we inherited from Taylor, which emphasized the subdivision of the system into its parts, but we are being forced to abandon it in favor of the more integrated view, in which the solution comes from the dynamics of the system as a whole and emerges from it, not from the sum of the isolated actions of the parts.Taylor's old scientific management gives place to a new science of business administration. “ 
The insertion of SMEsinto the competitive business scenario and the deep changes in the globalized market has required business management of fast and continuous strategy formulations, both at corporate strategy level and generic strategy level, with views to promote growth and competitiveness of the companies in different market segments. The cooperative strategy has proved to be a leveraging tool to increase the growth and development of SMEs.

\section{Results and Discussion}

The study was preceded of a review of literature with the goal of establishing the theoretical mapping of thematic approaches, viewing the conceptual foundation of the Systemic Dimension of Strategic Cooperation model, under a systems focus an approach is madeon business cooperation from the following dimensions: strategic management; organizational management; product and service management and marketing management. (Table 1).

Table 1- Theoretical framework of the systemic dimensions of strategic cooperation

\begin{tabular}{|l|l|l|}
\hline DIMENSIONS & \multicolumn{1}{|c|}{ THEMATIC APPROACH } & \multicolumn{1}{|c|}{ AUTHORS } \\
\hline Strategic Management & $\begin{array}{l}\text { Cooperative strategy } \\
\text { Strategy and systemic approach }\end{array}$ & $\begin{array}{l}\text { Franco; Silva; Porter; Hill et al ; } \\
\text { Katze Khan;Mintzenber; Wright et } \\
\text { al;Harbison e Pekar:Hooley, } \\
\text { Saunders e Piercy }\end{array}$ \\
\hline Organizational Management & $\begin{array}{l}\text { Organizational architecture } \\
\text { Organizational culture }\end{array}$ & $\begin{array}{l}\text { Nobrega; Peters e Waterman; Capra; } \\
\text { Hart; Farah: Morgan; Megliato e } \\
\text { Escrivão: Mintzenber }\end{array}$ \\
$\begin{array}{l}\text { Products and Services } \\
\text { Management }\end{array}$ & $\begin{array}{l}\text { Innovation } \\
\text { Competitiveness } \\
\text { Essential skills }\end{array}$ & $\begin{array}{l}\text { Franco; Porter ;Drucker ;Prahalad e } \\
\text { Hamel; Fahey;Meriño e Chordá }\end{array}$ \\
\hline Marketing Management & $\begin{array}{l}\text { Market segmentation } \\
\text { Market positioning } \\
\text { Marketing compound }\end{array}$ & $\begin{array}{l}\text { Almeida; Levit ; Kotler, Semenik e } \\
\text { Bamossy; Hooley,Saunders e Piercy; } \\
\text { Cobra }\end{array}$ \\
\hline
\end{tabular}

Therefore, based on this premise, the process of analysis and use of the tool - strategic cooperation - is based on small and medium enterprises and their dimensions, in terms of: 1) the type of strategy in businesses and / or corporative unit level; 2) the process of modeling the organizational architecture adjusted to the strategy; (3) the introduction of new production methods and processes, (4) the perspective on the needs and desires of consumers in relation to the products and / or services offered.

The Strategic Management subsystem, represented by the management of the company, aims to establish the policies and guidelines related to the cooperation strategy at the business unit level and / or at the corporate level. On the other hand, cooperation between companies also allows the integration of various players of different sizes - small and medium-sized enterprises (SMEs) and large enterprises. (Franco, 1998). For Hilt, Ireland and Hoskisson (2005), strategic alliances are the main form of cooperative strategies.Yet, Porter (1998) warns that alliances should be used as a selective tool, employed temporarily or involving nonessential activities. Hooley, Saunders, and Piercy (2001) also point to the fact that alliances bring many strategic risks and vulnerability, and require new managerial skills.

The Organizational Management subsystem has as its characteristic to establish the organizational architecture and to promote the cultural adaptation of the organization to the assumptions of the policies and guidelines related to the cooperation strategy. Drucker (1981) expresses that the structure follows the strategy. The organization is not mechanical, it can not be prefabricated or either assembled. The organization is something organic and unique for each business or institution. However, Harbison and Pekar Jr (1999) argue that the right structure is one that meets the needs and goals of the company. Only value creation is important. However, it needs to be consistent with the company's culture and the way decisions are made.Litterer (1980 p.165) advocates that: organizations are molded by the choices managers make, partly by considering the combinations that will best fit the environment, the production process, the technology employed, to the administrative tasks of the managers, and the needs aroused by the motivations of the members of the organization

The organizational culture is a very important variable for the success of cooperative strategies, but in particular, the strategic alliance. Cultural differences in management styles may lead to the discontinuation of strategic alliances Semenik and Bamossy (1995). The importance of institutional values is emphasized by Peters and Waterman (1982), when they affirm that any organization, in order to survive and achieve success, it must have a solid set of beliefs on which to base its policies and actions. However, it is observed that the symbiosis of different cultures between cooperating companies brings certain conflicts of culture and management styles, due to the natural resistance of people to change. 
Bowersox (1998) argues that developing attitudes toward the functioning of an alliance requires an open door and an open mind. This attitude is not easy for managers trained in a tradition of confrontational attitudes.

The subsystem of Product and Services Management has as a characteristic the methodological and technological process of production of goods and / or services. This subsystem addresses issues related to innovation, core competencies and competitiveness. Prahalad and Hamel (1998) point out that the key competences are the learning together in the organization, especially on how to coordinate the various production skills and integrate the multiple streams of technologies. Key competencies require collective organizational learning, involvement and commitment to integration through strategic business areas Nisembaum (2000). For Bateman and Snell (1998), when a company has essential competences in some area important for market success, these skills are the basis for the development of competitive advantages.

Innovation is a great challenge for organizations. For companies, the process of innovation is related to discoveries of new methods, production processes, new technologies that transform and differentiate products or services for a particular consumer market. Trout and Rivkin (2000) place the differentiation of goods and services of a company and the competitor as the great secret for the survival of the organization. Now Gracioso (1997) says that basically there are two paths that lead to innovation and the changes in the company: (1) innovations in the production process; and (2) innovation in the marketing and sales process. Drucker (1981), with its pragmatic approach, describes it as follows:

Innovation is not a technical term. It is an economic and social term. Its criteria is not science or technology, but a change in the economic or social scenario, a change in the behavior of people with consumers or producers, with citizens, students or teachers or whatever else. Innovation creates new wealth or a new potential for action rather than new knowledge.

Nevertheless, the process of innovation is based on a set of organizational variables that conducts the structure and functioning of the administrative systems of a given company, of which sometimes impose restrictions and resistance to the process of change. A corporation's systems and bureaucracies generally reject any novelty Pinchot III (1989). Franco (2003) argues in this line stating that many small companies, with rigid structure and weak business dynamics, have difficulties to become innovative.

On the other hand, there is a paradox about the innovation process which we call imitation. Levitt (1990) defines it as innovative imitation and describes it as a reverse $\mathrm{R} \& \mathrm{D}$, that is, try to create its own imitative equivalents of innovative products created by thirds.

Competitiveness is also a thematic approach to this subsystem. According to Prahalad and Hamel (1998), a company's competitiveness derives from its price / performance attributes on existing products. For Porter (1989), competitive strategy seeks to establish a profitable and sustainable position against the forces that determine competition in industry. And Fahey (1999) advocates the adoption of a competitive position for companies as a way of differentiating themselves from current and future competitors, according to the perception and comprehension of the clients. For Moreira and Oliviere Neto (1998) it is through the competitive process that companies seek basic growth strategies, increase market share and maximize profitability. Meriño and Chordá (2005) emphasize that the understanding of competitiveness must take into account the following factors of competence: in towardsness; in quality management; in human resources; in marketing management; in technology management; in organization; in productive system; in costs and financing.

The Marketing subsystem has as attributes the development of the company's marketing strategies, from the conception to the development, implantation and evaluation of a particular product or service with the consumer. Almeida (2000) defines marketing as a process of administrative and social management, where the organization tunes in to the needs and desires of its consumers, creates a product and / or service and establishes a relationship of exchange of values with its target market. For Cobra (1993); Richers (2000) marketing translates itself into the way of feeling, understanding and serving the market.According to Kotler (1996), marketing has as its main responsibility the achievement of growth in profitable recipes for the company. Another point is that marketing establishes a direct relationship between the customer and the company. Customers assign values to products and services in a direct proportion that these products have to meet their Wing (1998) requirements.

The market approach is centered on the aspects about market segmentation; composed of marketing and market positioning. The market segmentation as the division of a total market for products and / or services into smaller parts of the market on a demographic, geographical, psychographic, and behavioral basis (Etzel, Walker and Stanton (2001) (Kotler (1996) Cobra (1992) Wesinsten (1995) .The marketing compound is described as the set of tangible and intangible attributes that designates the essential characteristics of the offer of a given product to the consumer. It is resultantof the following elements: price, product, distribution and communication (Almeida (2001) Kotler (1996) Cobra (1993) Semenik and Bamossy (1995)). 
The market positioning comprehends the development of strategies selected and focused on a set of significant differences, related to products or services offered, leading the consumer to value and to make an association with the company's image (Moreira and Olivieri Neto (1998); Semenik and Bamossy (1995) Richers (2000) Souza (1999)).

\section{Final Considerations}

The application of the Systemic Dimensions of Strategic Cooperation model will allow an understanding of strategic cooperation and the context of the organizational reality of SMEs, from the point of view of systemic management. The study and evaluation of the strategic cooperation process, from the strategic management dimensions, that is organizational, of products or services and marketing, will allow understanding the management mechanisms of SMEs and how these subsystems interact and transform their results into competitive advantages.

On the other hand, the conceptual model with its respective approaches applied to its dimensions will allow the formulation of a series of questionings related to the process of strategic cooperation by Small and Medium Enterprises. As a contribution to future discussions, among many possible questions, we have listed some of them:

How are strategic partnerships in SMEs formulated and implemented? How are stakeholder issues addressed by donors? How are the cooperative market segments structured? How do environmental aspects influence the process of strategic alliances? How can we evaluate the potential that cooperating partners have to offer? How do we manage the alliance process among the donors? What is the organizational architecture model and the human resources profile? What are the technical, budgetary and administrative implications and difficulties that aid workers have to adapt to strategic cooperation? How does strategic cooperation contribute to the marketing and product and / or service management of cooperating companies? What are the cultural and political changes that come with the implementation of strategic cooperation? Have strategic partnerships increased the process of innovation and competitiveness in small and medium-sized enterprises?

Anyway. In addition to these questions, aimed at understanding the structure and functioning of business cooperation, the conceptual model for studying strategic cooperation in small and medium-sized enterprises broadens the search horizon to understand the competitive evolution of small and medium-sized organizations. Companies that transpose the barriers of market competition and leverage their core competencies with cooperation strategies consolidate their business and, above all, creates a virtuous circle by building and renewing their potential, of which we call the generation of competitive advantages. This continuous process of generating essential competences is consolidated in the creation of values for Company. And this is the main foundation for small and medium companies to adopt strategic cooperation as an instrument of growth and development of their business.

\section{References}

ALMEIDA, Francisco Alberto Severo, Marketing Aplicado à Gestão Educacional, Universidade Estadual de Goiás, Uniciência, Anápolis, v.7, nº 1 e 2, p. 53-78, 2000.

Aplicação da teoria geral de sistemas no orçamento da União, UnB Contábil- Departamento de Ciências contábeis e Atuariais da Universidade de Brasília, Brasília, Departamento, 1998, primeiro semestre de 2000, V3, n.1, p 111-125.

,( 2001)Marketing em Serviços Educacionais, Brasília, Fubrae,.

ANDRADE, J.H.; Carvalho, K.C.; Escrivão Filho, E. Gestão da informação na pequena empresa: identificação de tipos e fontes de informação relevantes para a administração estratégica. In: XI Simpósio de Engenharia de Produção - SIMPEP, 8 a 10 de novembro de 2004, Bauru: Faculdade de Engenharia - Universidade Estadual Paulista - UNESP. Disponível em: <http://www.simpep.feb.unesp.br/07.html>

BATEMAN, Thomas S. e Scott A Snell, (1998).Administração: construindo vantagem competitiva,revisão técnica José Ernesto Lima Gonçalves, Patrícia Cunha Tavares, São Paulo, Atlas.

BNDES, Micros , pequenas e médias empresas, available from internet :http://www.bndes.gov.br/pme/default.asp< acesso 06.07.2006>

BROWERSOX, Donald J. (1998.)Os benefícios estratégicos das alianças logísticas. In: Estratégia: a busca da vantagem competitiva., Cynthia Montgomery e Michael Porter, (Org).Harvard Business Review Book, Rio de Janeiro , Campus ,

CAPRA, Fritijof, (1998) O ponto de mutação- a ciência, a sociedade e a cultura emergente, São Paulo,Cultrix.

CHÉR,Rogério. (1990). A gerência das pequenas e médias empresas : o que saber para administrá-las, São Paulo, Maltese,

COBRA, Marcos, (1993) Marketing competitivo, São Paulo, Atlas,. 
, (1992)Administração de Marketing, 2. ed. , São Paulo, Atlas,

DMPME - Departamento de Micro e Pequena e Média Empresa -, Micro, pequenas e médias empresas: definições e estatísticas internacionais , disponível em:<http/:www.mdic.gov.br> acesso 15.6.2006.

DRUCKER, Peter,( 1981) Fator humano e Desempenho, o melhor de Peter Drucker sobre administração. São Paulo, Pioneira,1981.

ETZEL, Michael J., Bruce J.Walker e William J.Stanton ,( 2001) Marketing ; tradução técnica Arão Sapiro, São Paulo ,Makron Books,.

EURO INFO CENTRE, EIC PME, Perguntas mais frequentes, available frominternet :http://www.eicpme.iapmei.pt/eicpme_faq_02.php?tema, acesso 22.07.2016

FARAH, Elias,( 2001.) Empreendedorismo Estratégico.In: Gestão estratégica de negócios, evolução,cenários, diagnósticos e ação, Marly Cavalcanti (Org), São Paulo, Pioneira Thomson Learning,

FRANCO, Mário José Batista,(2003) Collaboration among SMEs as a mechanism for innovation: an empirical study, New England Journal of Entrepreneurship, v 6, $\mathrm{n}^{\circ} 1$,.

Estratégia de cooperação nas PME da Região da Beira Interior: características dos acordos analisados, Revista Portuguesa de Gestão, INDEG/ISCTE, V.1 p.41-50,1998.

A cooperação empresarial em Portugal: fatores críticos de sucesso, Revista de Gestão e Economia, Universidade da Beira, ${ }^{\text {o }}$ 1, p.33-39, 2001.

GRACIOSO, Francisco, (1997)Marketing : o sucesso em 5 movimentos,São Paulo, Atlas,

HART, Ellen R.( 1999.) Mudança estratégica: reconfigurando os processos operacionais para a implementaçao da estratégia. In: MBA Curso prático de estratégia, Liam Fahey e Robert M. Randal(Org), tradução de Afonso Celso da Cunha Serra, Rio de Janeiro,Campus,

HARBISON, John R. e Peter Pakar Jr. (1999.)Alianças estratégicas: quando a parceria é a alma do negócio e o caminho do sucesso, tradução Maria Lúcia Leite Rosa, São Paulo, Futura,

HILL, Charles W.L e Garrete R. Jones,(1998). Strategic Management and integrated approach, Fourth Edition, Boston, New York, Houghton Mifflin Company,

HOOLEY, Graham J., John A. Saunders e Nigel F. Piercy,( 2001) Estratégia de marketing e posicionamento competitivo, 2. ed.,tradução técnica: Arão Sapiro, São Paulo, Prentice Hall,

HILT, Michael A., R. Duane Ireland e Robert E. Hoskisson,(2005.)Administração estratégica : competitividade e globalização; tradução de José Carlos Barbosa dos Santos e Luís António Pedroso Rafael, São Paulo,Pioneira Thomson Learning,

JULIO, Carlos Alberto e José Salibi Netol (org), Estratégia e planejamento, autores e conceitos imprescindíveis, In; A hora da estratégia: entrevista com Machael Porter,São Paulo ,publifolha,2002,p.187-191.

KATZ, Daniel e Kahn, Robert, (1987)Psicologia social das organizações, 3 ed. São Paulo, Atlas,.

KOTLER, Philip, (2007)Marketing para o século XXI: como criar, conquistar e dominar mercados; tradução Bazán Tecnologia e Lingüistica, São Paulo, Futura,.

(1996)Administração de marketing: análise , planejamento, implementação e controle; tradução Ailton Bonfim Brandão, 4. ed.,São Paulo, Atlas,

LITTERER, Joseph A ,(1980) Introdução a administração,tradução de José Ricardo Brandão Azevedo, Rio de Janeiro, Livro Técnicos e Científicos,.

LEVITT, Theodore ,( 1996) A imaginação de marketing , tradução Auríphebo Berrance Simões e Nivaldo Montingelli, 2. ed. , São Paulo, Atlas.

MERIÑO e Chordá , Gestión para la competitividad en empresas de las producciones mecánicas, una aplicación práctica , Universidade Estadual de Goiás, Revista Plurais, v. 1, n 2, Anápolis, p.9-44, 2005.

MITINZBER, Henry ,(1998). A criação artesanal de estratégia. In: Estratégia: a busca da vantagem competitiva., Cynthia Montgomery e Michael Porter, (Org).Harvard Business Review Book, Rio de Janeiro, Campus .

MORGAN, Gareth, (2009) Imagens da organização: tradução Cecília Whitaker Bergamini, Roberto Coda, São Paulo, Atlas,.

MOREIRA, Júlio César Tavares e Rafael Olivieri Neto,(1998) Marketing Business to Business: é fazer ou morrer, São Paulo, Makron Books.

NISEMBAUM, Hugo,( 2000) A competência essencial, São Paulo, Ed. Infinito.

NÓBREGA, Clemente,( 1996) Em busca da empresa quântica: analogias entre o mundo da ciência e o mundo dos negócios, Rio de Janeiro, Ediouro.

PRAHALAD C.K. e Gary Hamel ,(1998) A competência essencial da corporação. In: Estratégia: a busca da vantagem competitiva., Cynthia Montgomery e Michael Porter, (Org).Harvard Business Review Book, Rio de Janeiro , Campus . 
PETERS, Thomas J e Robert H Waterman Jr.,(1982) Vencendo a crise como o bom senso empresarial pode superála,3.ed .São Paulo, Ed Harper \& Row do Brasil.

PINCHOT III , Gifford ,( 1989) Intrapreneuring - porque você não precisa deixar a empresa para torna-se um empreendedor, , São Paulo,Editora Harbra ltda,.

PORTER, Michael. (1998)vantagem competitiva das nações. In: Estratégia: a busca da vantagem competitiva., Cynthia Montgomery e Michael Porter, (Org).Harvard Business Review Book, Rio de Janeiro, Campus .

(2002) .Vantagem competitiva , criando e sustentando um desempenho superior,Rio de Janeiro,Campus ,1989..

RICHERS , Raimar,( 2000) Marketing uma visão brasileira, São Paulo, Negócios Editora

SEBRAE, Estudos e Pesquisa, available from internet: http://www.sebrae.com.br/br/ aprendasebrae/ estudosepesquisas.asp< acesso em 06.07.2016>.

SEBRAE - Serviço Brasileiro de Apoio as Micro E Pequenas Empresas e DIEESE - Departamento Intersindical de Estatística e Estudos Socioeconômicos.(2014)Anuário do Trabalho na Micro e Pequena Empresa 2014. São Paulo: Sebrae; Dieese,.

SEMENIK , Richard J. e Gary J. Bamossy , (1995)Princípios d e Marketing: uma perspectiva global;tradução Lenke Peres, revisão Arão Sapiro, São Paulo, Makron Books,.

SILVA, C.A.V. Redes de cooperação no Brasil e no mundo : uma abordagem reflexiva. In: IV Encontro de Estudos sobre Empreendedorismo e Gestão de Pequenas Empresas (EGEPE), 15 a 17 de maio de 2005, Curitiba (PR): Pontifícia Universidade Católica do Paraná (PUC-PR); Universidade Estadual de Maringá (UEM); Universidade Estadual de Londrina (UEL). 1 CD-ROM. ISSN 1518-3734.

WESINSTEN, Art, (1995.)Segmentação de mercado: tradução Celso A . Rimoli, São Paulo,Atlas,

TROUT e Rivkin,(2000) Diferenciar ou morrer, sobrevivendo em uma era de competição mortal: tradução Eduardo Lassere, São Paulo, Futura.

WING, Michael J.( 1998) Como falar com seus clientes: o que eles têm a contar sobre a sua empresa quando você faz as perguntas certas; tradução de Luiz Euclydes Trindade Frazão e Lenke Peres, Rio de Janeiro, Campus.

WRIGHT, Peter, Mark J. Krool e John Parnell,( 2011) Administração estratégica : conceitos, tradução Celso A. Rimoli, Lenita R. Esteves, São Paulo, Atlas,. 